\title{
Correction: Epistasis of HTR1A and BDNF risk genes alters cortical 5-HT1A receptor binding: PET results link genotype to molecular phenotype in depression
}

Alexander Kautzky', Gregory M. James', Cecile Philippe², Pia Baldinger-Melich', Christoph Kraus', Georg S. Kranz ${ }^{1}$, Thomas Vanicek1, Gregor Gryglewski ${ }^{1}$, Annette M. Hartmann ${ }^{3}$, Andreas Hahn', Wolfgang Wadsak $\mathbb{E}^{2,4}$,

Markus Mitterhauser ${ }^{2,5}$, Dan Rujescu ${ }^{3}$, Siegfried Kasper ${ }^{1}$ and Rupert Lanzenberger ${ }^{1}$

\section{Correction to: Translational Psychiatry}

https://doi.org/10.1038/s41398-018-0308-2

published online 16 January 2019

In the original Article, co-author Professor Andreas Hahn was not included in the author list. This has been corrected in the XML, PDF and HTML versions of this Article.

Published online: 04 October 2019

Correspondence: Rupert Lanzenberger (rupert.lanzenberger@meduniwien.ac. at)

${ }^{1}$ Department of Psychiatry and Psychotherapy, Medical University of Vienna, Wien, Austria

${ }^{2}$ Division of Nuclear Medicine, Department of Biomedical Imaging and Imageguided Therapy, Medical University of Vienna, Wien, Austria

${ }^{3}$ University Clinic for Psychiatry, Psychotherapy and Psychosomatic, Martin-

Luther-University Halle-Wittenberg, Halle, Germany

${ }^{4}$ Center for Biomarker Research in Medicine (CBmed), Graz, Austria

${ }^{5}$ Ludwig Boltzmann Institute Applied Diagnostics, Vienna, Austria

(c) The Author(s) 2019

(c) (i) Open Access This article is licensed under a Creative Commons Attribution 4.0 International License, which permits use, sharing, adaptation, distribution and reproduction in any medium or format, as long as you give appropriate credit to the original author(s) and the source, provide a link to the Creative Commons license, and indicate if changes were made. The images or other third party material in this article are included in the article's Creative Commons license, unless indicated otherwise in a credit line to the material. If material is not included in the article's Creative Commons license and your intended use is not permitted by statutory regulation or exceeds the permitted use, you will need to obtain permission directly from the copyright holder. To view a copy of this license, visit http://creativecommons.org/licenses/by/4.0/. 